\title{
The matrix (M) protein of Newcastle disease virus binds to human Bax through its $\mathrm{BH} 3$ domain
}

\author{
Aidin Molouki ${ }^{1}$, Yi-Te Hsu' ${ }^{2}$, Fatemeh Jahanshiri ${ }^{1}$, Syahril Abdullah ${ }^{3}$, Rozita Rosli ${ }^{3}$ and Khatijah Yusoff ${ }^{1,4^{*}}$
}

\begin{abstract}
The underlying mechanisms by which Newcastle disease virus (NDV) kills cancer cells are still unclear. Recent discoveries have shown that many viruses contain $\mathrm{Bcl}-2$ homology-like domains which enabled their interaction with Bcl-2 family members, and thereby accounting for their virulence and pathogenicity. Alignment of the protein sequences of Malaysian strain of NDV, known as AF2240, with those from members of the human BCl-2 family showed many similar regions; most notably we found that its matrix (AF2240-M) protein, large (AF2240-L) protein and fusion (AF2240-F) protein all contain BH3-like regions. In addition, there are BH1-like domains in these proteins, where AF2240-F and Mcl-1 share 55\% identity within this region. To further investigate our hypothesis that the presence of the BH3-like domains in these proteins may convey cytotoxicity, AF2240-M and AF2240-F genes were cloned into pFLAG and pEGFP.N2 vectors and transfected into HeLa cells. The expression of these constructs promoted cell death. As shown by flow cytometry, AF2240-M protein with deleted BH3-like region showed fivefold decrease in apoptosis. Moreover, the construct containing the N-terminal of AF2240-M showed nearly the same cell death rate as to that of the full-length protein, strongly suggesting that the $\mathrm{BH} 3$-like domain within this protein participates in promoting cell death. Moreover, AF2240-M transfection promoted Bax redistribution to mitochondria. Therefore, to determine whether there is any direct interaction between NDV viral proteins with some members of the Bcl-2 family, various constructs were co-transfected into HeLa cells. Co-immunoprecipitation trials showed that the AF2240-M indeed directly interacted with Bax protein via its BH3-domain, as the mutant proteins failed to interact with Bax. AF2240-F failed to interact with any of the tested proteins, although BCI-XL slowed down the rate of cell death caused by this construct by nearly five-fold. In a parallel experiment, the level of expression of endogenous Bax and BCl-2 after infection of HeLa cells with NDV was assessed by qRT-PCR, but no statistically significant change was observed. Consequently, the Bax/BCl-2 ratio at the mRNA level did not alter. Overall, our study has shed additional light into the mechanisms by which NDV induces apoptosis.
\end{abstract}

Keywords: NDV, AF2240, Apoptosis, Matrix protein, Fusion protein, Bcl-2 homology domain, Protein-protein interaction, HeLa

\section{Introduction}

Newcastle disease virus (NDV), an avian paramyxovirus, affects most species of birds and is considered one of the most devastating viruses that can cause great economic damage to the poultry industry [1]. Its many strains have been mainly categorised by its pathotype and clinical effects rather than by its structure. Strain AF2240 is a viscerotropic velogenic strain of NDV that causes a high mortality rate and was isolated during an

\footnotetext{
* Correspondence: kyusoff@mosti.gov.my

${ }^{1}$ Department of Microbiology, Faculty of Biotechnology and Biomolecular Sciences, Universiti Putra Malaysia, 43400 UPM, Serdang, Selangor DE, Malaysia

Full list of author information is available at the end of the article
}

outbreak in the country in the 1960s. It is now used as the challenge virus in vaccine trials in Malaysia [2].

NDV belongs to the genus Avulavirus from the family of Paramyxoviridae [3]. It has a non-segmented singlestranded negative-sense RNA genome of nearly $15 \mathrm{~kb}$ [4-6]. The virion is enveloped with a lipid bilayer membrane derived from the host cell membrane [7]. This structure consists of 6 proteins. HN and F fusion glycoproteins are embedded in the lipid membrane. The matrix $(\mathrm{M})$ protein is associated with the inner surface of the membrane. Inside the virion, three proteins, nucleocapsid (NP), phosphoprotein (P), and large (L) protein, constitute the viral transcriptase complex. The
C Biomed Central

() 2011 Molouki et al; licensee BioMed Central Ltd. This is an Open Access article distributed under the terms of the Creative Commons Attribution License (http://creativecommons.org/licenses/by/2.0), which permits unrestricted use, distribution, and reproduction in any medium, provided the original work is properly cited. 
interaction between these macromolecules and their binding domains have yet to be defined completely [7]. Upon entry into the host cell, NDV genome is subjected to two separate mechanisms of transcription and replication that result in the production of more viruses.

The F glycoprotein mediates virus fusion with the host cellular membrane. Its gene has $1791 \mathrm{bp}$ with an open reading frame of $1662 \mathrm{bp}$ and it codes for F0 precursor with 553 amino acids. The precursor is then cleaved at residues $116-117$ to generate F1 and F2 disulphidelinked polypeptides $[8,9]$. The transmembrane domain of $\mathrm{F}$ is located at the $\mathrm{C}$-terminal region of $\mathrm{F} 1$. Three hapted repeat sites have been reported that are strain specific [10] and also six glycosylation sites have been previously identified [11].

The M gene of strain AF2240 has 1223 bp with an ORF of $1093 \mathrm{bp}$. Its translated product contains 364 amino acids for all reported strains and has a molecular weight of approximately $40 \mathrm{kDa}$ [11]. It is relatively hydrophobic and non-glycosylated with many basic residues. It has been reported that $\mathrm{M}$ is associated with the $\mathrm{N}$-terminal segment of $\mathrm{HN}$ protein located in its inner surface [12]. It is also believed that it interacts with the NP protein, but the exact binding domains are yet to be determined [7]. The nucleocapsid itself is a herringbone-like structure comprising thousands of NP subunits that are associated tightly with several copies of $\mathrm{P}$ and $\mathrm{L}$ proteins.

NDV appears to selectively kill cancer cells while sparing normal human cells [13]. It is believed that NDV kills avian cells and human cancer cells by apoptosis [14-16]. On the other hand, cell death through apoptosis is initiated via either intrinsic or extrinsic pathway [17]. The Bcl-2 family of proteins plays an important role in the regulation of mitochondrial checkpoints that are involved in both intrinsic and extrinsic apoptotic signaling pathways [18]. These proteins display both pro- and anti-apoptotic functions [19] and have one or more of the conserved domains known as the Bcl-2 homology (BH) domains 1 to 4 . These family members can interact with each other or other proteins via these conserved domains.

Numerous publications have demonstrated the antior pro-apoptotic effects of viruses and their respective viral proteins in eukaryotic cells [20], but it is only recently that researchers have begun to investigate the sequence similarity between viral proteins and cellular apoptotic proteins. Since the late 20th century, it was shown that some viruses contain protein homologs to $\mathrm{Bcl}-2$ family members and that many of these domains enable these proteins to interact with Bcl-2 family members [21-29]. These studies provide an initial clue on the underlying mechanisms behind the apoptosis regulating effect of these viruses.
Here, we report for the first time that NDV viral proteins contain BH domain-like regions, and that AF2240$\mathrm{M}$ and AF2240-F display pro-apoptotic effect in HeLa cells. Previously, it was shown that strain AF2240 has a different $\mathrm{HN}$ protein compared to that of other strains [30]. However, now we show that there are additional unique features within the $\mathrm{BH} 1-$ and $\mathrm{BH} 3$-like regions in $\mathrm{M}, \mathrm{F}$ and $\mathrm{L}$ proteins of strain AF2240, and that AF2240-M interacts with human Bax protein by its BH3 domain.

\section{Materials and methods \\ Cell culture}

Human cervical cancer cell line, HeLa, was purchased from American Type Culture Collection (ATCC) and cultured in Dulbecco's modified Eagle's medium (DMEM) supplemented with $10 \%$ fetal bovine serum (FBS), $100 \mathrm{U}$ of penicillin/ml and $100 \mu \mathrm{g}$ of streptomy$\mathrm{cin} / \mathrm{ml}$ in $5 \% \mathrm{CO}_{2}$ at $37^{\circ} \mathrm{C}$, and routinely checked for mycoplasma contamination. The cells were infected with NDV as previously described [15].

\section{qRT-PCR}

Real-Time RT-PCR was performed with a two-step system optimized for use with Rotor-Gene 6000 Real-Time PCR machine (Corbett, Australia). Briefly, at different time points post-infection, HeLa cells were harvested and total cellular RNA was isolated using RNeasy Mini kit (Qiagen, USA). cDNA was prepared with a QuantiTect ${ }^{\mathbb{B}}$ RT system (Qiagen, USA) according to manufacturer's instructions. Next, normalized cDNAs were used in a Hotstart qPCR with Rotor-Gene SYBR green kit (Qiagen, USA) together with Bax and Bcl-2 QuantiTect primer sets (Qiagen, USA). The cycling conditions started with initial $5 \mathrm{~min}$ at $95^{\circ} \mathrm{C}$ followed by $35-40$ two-step cycles of $5 \mathrm{sec}$ at $95^{\circ} \mathrm{C}$ and $10 \mathrm{sec}$ at $60^{\circ} \mathrm{C}$. A melting curve analysis was performed in the end of the reaction to verify the specificity and identity of the PCR products. Finally, the $\Delta \Delta \mathrm{Ct}$ [ $=(\mathrm{Ct}$ of target gene in sample - Ct of housekeeping gene in sample) - (Ct of target gene in control - Ct of housekeeping gene in control)] and expression $\left(2^{-\Delta \Delta C t}\right)$ values were calculated.

\section{Protein sequence analysis}

All protein sequence alignments were performed with SIM+LALNVIEW at ExPASy proteomics server http:// 192.33.215.47/tools/sim-prot.html. Protein BLAST (BL2SEQ) was used to identify sequence similarities between NDV viral proteins and human cellular proteins. Prediction of transmembrane helix and intervening loop region was done by TMHMM software, and prediction of secondary structures was done by PELE software, both of which are located at San Diego supercomputer center server http://workbench.sdsc.edu/. 


\section{Plasmid constructs}

Total RNA was extracted with QIAamp Viral RNA Mini Kit (Qiagen, USA) from pure stock of Malaysian strain of NDV strain AF2240, which was grown in 9-day old embryonated chicken eggs and purified as previously described [31]. cDNA was made with RevertAid kit (Fermentas, USA). Specific primers were used for amplifying the cDNAs to enable tagging and cloning of AF2240-M and AF2240-F viral genes. The PCR primers used for subcloning the AF2240-M gene into pFLAG-CMV-5a vector (Mammalian carboxy-terminal FLAG transient expression kit, Sigma, USA) were 5'-CTTGGAATTCACCATGGACTCATCCAGGGCAATC-3' for forward and 5'-CTTGGTCGACTTTTTTGAAAGGGTTGTATT TAGC-3' for reverse. The pFLAG-M-N-terminal mutant was generated by the same forward primer but with a different reverse primer, 5'-CTTGGTCGACTTGTGG GGTGATTTGCTTCTT-3' to amplify 40 a.a. of the Nterminal. The AF2240-F gene primers used for PCR amplification and subcloning into the same vector were 5'-CTTGGAATTCACCATGGGCTCCAAGTCTTCTACC-3' for forward and 5'-CTTGGTCGACTGTT CTTGTGGTGGCTCTCAT-3' for reverse. Restriction endonuclease sites EcoRI and SalI were chosen for subcloning the PCR fragments into the MCS site of the pFLAG vector. The AF2240-M gene PCR primers used for subcloning into pEGFP.N2 (Clontech, USA) were 5'AGCTCAAGATCTACCATGGACTCATCCAGGGCA3 ' for forward and 5'-GAGGTCAAGCTTGCGAAAGGG TTGTATTTAGCA-3' for reverse (restriction endonuclease sites BglII and HindIII) having two extra nucleotides (in bold) to clone in the same reading frame of the EGFP tag. Also, a Kozak's ACC sequence (in bold) was included in all forward primers to promote the translation of the target genes in eukaryotic cells. PCR was carried out with a recombinant $p f u$ DNA polymerase (Fermentas, USA). All PCR products were gel purified and were first cloned into pJET vector (CloneJET PCR cloning kit, Fermentas, USA) to increase PCR product quantity and enhance the chance of cloning to the main target vectors. Generation of pGFP-Bax, pGFP-Bad and pGFP-Bcl-XL has been described previously [32]. pcDNA3-FLAG-BimL was a kind gift from Professor Roger Davis, MIT Medical School, Boston, MA, USA. All plasmids were transformed into TOP10 E. coli, grown in LB broth and extracted with PureLink kit from Invitrogen.

\section{Generation of AF2240-M- $\triangle \mathrm{BH} 3$ deletion mutant}

The plasmid pFLAG-M- $\triangle B H 3$ was produced by deletion of the BH3-like domain in AF2240-M gene. Briefly, two primers flanking the region between base pairs 67-111 were designed in a way to not disturb the FLAG-tag reading frame (Forward: 5'-ACCCCACAATACAGGAT
CCAG-3' and Reverse: 5'-TGCTAATAGGCTGCTGGAGGGAAG-3'). PCR was run for 20 cycles with $50 \mathrm{ng}$ of pFLAG-M as template. Recombinant $p f u$ DNA polymerase was used to proof-read the entire product. Later, the PCR product was subjected to digestion with $D p n 1$ enzyme to eliminate the methylated template DNA. After gel purification, the linear PCR product was ligated with T4 ligase for $3 \mathrm{~h}$ at RT, and then transformed into TOP10 E. coli.

\section{Co-transfection and fluorescent microscopy}

For transfection, HeLa cells were cultured in $10 \mathrm{~cm}$ in diameter plates at $2 \times 10^{5}$ cells/plate. The next day, at a confluency of $70-80 \%$, the medium was removed and cells were washed with PBS. Transfection or co-transfection of cloned plasmids were done with Lipofectamine LTX and PLUS reagent (Invitrogen, USA) according to manufacturer's instructions. Cells were analyzed between $12 \mathrm{~h}$ to $48 \mathrm{~h}$ post-transfection by flow cytometery, coimmunoprecipitation, light and fluorescent microscopy.

\section{Flow cytometry and PI staining}

On the day of experiment, cells were detached with Accutase (PAA, USA) and washed with cold PBS (pH 7.4). Floating cells in medium which had died after transfection were also collected. The pellets were resuspended in ice-cold absolute ethanol to fix cells. Cells were kept in $-20^{\circ} \mathrm{C}$ freezer until they were pelleted down at the time of experiment. Three hundred microliters of Propidium iodide $(1 \mu \mathrm{g} / \mathrm{ml})$ containing $10 \mu \mathrm{g} / \mathrm{ml}$ DNasefree RNase A in PBS was added to each fixed cell pellet. The pellets were resuspended and incubated for $10 \mathrm{~min}$ before addition of a same volume of sheath buffer. The stained cells were then analyzed with BD FACSCanto II flow cytometer. The data were analysed with BD FACSDiva and Cyflogic softwares.

\section{Subcellular fractionation}

Subcellular fractionation was performed as previously described [15]. Briefly, transfected cells were collected at different time points and resuspended in mitochondrial buffer $(70 \mathrm{mM}$ Tris- $\mathrm{HCl}, 0.25 \mathrm{M}$ sucrose and $1 \mathrm{mM}$ EDTA, pH 7.4). An equal volume of ice-cold digitonin lysis buffer (2 mg/ml, $19.8 \mathrm{mM}$ EDTA, 0.25 M D-mannitol and $19.8 \mathrm{mM}$ MOPS, $\mathrm{pH}$ 7.4) was added for $90 \mathrm{~s}$. Samples were then centrifuged twice at $300 \mathrm{~g}$ for $5 \mathrm{~min}$ to pellet the nuclei. The supernatant was further centrifuged at $17,000 \mathrm{~g}$ for $20 \mathrm{~min}$ to separate mitochondria from the cytosol. The supernatant was then subjected to SDS-PAGE and Western blotting with mouse monoclonal anti-Bax 2D2 antibody (Invitrogen, USA).

\section{Co-immunoprecipitation}

In order to study protein-protein interactions, the coimmunoprecipitation approach was tried. A FLAG kit 
(Sigma, USA) was used in all Co-IP trials. Briefly, all transfected cells were harvested and washed with PBS twice before being resuspended in $100 \mu \mathrm{L}$ of $2 \%$ CHAPS lysis buffer (2\% CHAPS, $10 \mathrm{mM}$ HEPES $\mathrm{pH}$ 7.4, $150 \mathrm{mM} \mathrm{NaCl}$, and 1 tablet of Roche cOmplete ${ }^{\mathrm{TM}}$ protease inhibitor) $[33,34]$. After quantification with Bradford method, the normalized cell lysates were added to $0.5 \mathrm{~mL}$ microtubes containing $40 \mu \mathrm{L}$ of antiFLAG M2 affinity gel. For positive control, $200 \mathrm{ng}$ of FLAG-BAPTM fusion protein was used. The microtubes were rotated end-to-end at $4{ }^{\circ} \mathrm{C}$ overnight. After incubation, the microtubes were centrifuged at $8000 \mathrm{~g}$ for $30 \mathrm{sec}$. The supernatants were removed and the resins were washed twice with $0.5 \%$ CHAPS buffer. The cleaned resins were then resuspended in $30 \mu \mathrm{L}$ of SDS-PAGE sample buffer and boiled for $10 \mathrm{~min}$. The microtubes were then centrifuged at maximum speed for $5 \mathrm{~min}$ and the supernatants were used in SDSPAGE and Western blotting.

\section{SDS-PAGE and Western blotting}

Proteins in the SDS-polyacrylamide gel were electrotransferred onto Immobilon-P membrane (Millipore Corp., USA) and after transferring, the membrane was blocked with a casein buffer (Pierce, USA). The membrane was incubated either with a monoclonal antiFLAG clone M2 raised in mouse (Sigma, USA), or polyclonal anti-GFP ab290 raised in rabbit (Abcam, USA) at a dilution of $1: 1000$ overnight at $4{ }^{\circ} \mathrm{C}$. The blot was then respectively incubated with an $\mathrm{AP}$-conjugated goat antimouse (Bethyl, USA), or AP-conjugated goat anti-rabbit (Sigma, USA) at a dilution of 1:1000 for $1 \mathrm{~h}$ at room temperature. NBT/BCIP alkaline phosphatase buffer (100 $\mathrm{mM}$ Tris- $\mathrm{HCl} \mathrm{pH}$ 9.5, $100 \mathrm{mM} \mathrm{NaCl}, 10 \mathrm{mM} \mathrm{MgCl}$, containing $3 \mathrm{mg} / \mathrm{ml} \mathrm{NBT}$ and $1.5 \mathrm{mg} / \mathrm{ml} \mathrm{BCIP)}$ was used to develop the blotted membrane (Fermentas, USA).

\section{Statistical analyses}

All statistical analyses were performed by Microsoft Excel. All error bars indicate the standard error of the mean (SEM). p-values less than $0.05(*), 0.01(* *)$ and $0.001{ }^{(* * *)}$ reject the null hypothesis and are referred as statistically significant.

\section{Results \\ Infection of HeLa cells with NDV did not alter Bax and Bcl-2 mRNA levels}

HeLa cells were infected with NDV and their RNA was extracted at different time points post-infection. A relative comparison of the expression of endogenous Bax and Bcl-2 before and after NDV infection was studied. Real-Time PCR with the generated cDNA was carried out and $\Delta \mathrm{Ct}, \Delta \Delta \mathrm{Ct}$ and expression $\left(2^{-\Delta \Delta \mathrm{Ct}}\right)$ values were calculated according to the $\mathrm{Cts}$ of samples and controls
(Figure 1). The values were compared to that of the housekeeping gene $18 \mathrm{~S}$ rRNA. Surprisingly, the mRNA levels of Bax and Bcl-2 before and after NDV infection did not alter much as no notable increase or decrease was observed in the $\mathrm{Ct}$ values during multiple trials. Thus, the ratio between Bax and Bcl-2 did not show a statistically significant alteration following NDV infection (Figure 1D). At $24 \mathrm{~h}$ post-infection many cells died and detached. These cells were collected separately from adherent infected cells. For easier presentation, the uninfected cells, adherent infected cells and floating infected cells were marked as U, A and F, respectively.

\section{Multiple BH domain-like regions in NDV viral proteins}

By BLASTing NDV viral protein sequences in the BL2SEQ online software at NCBI website, we found many similar regions between these six proteins $(\mathrm{M}, \mathrm{L}, \mathrm{F}$, HN, NP, P) and human cellular proteins (Table 1). Surprisingly, AF2240-M protein scored the highest in terms of sequence homology to some mammalian proteins such as RAS p21 activator, B-cell transcription factor 4, and spectrin beta chain, compared to other viral proteins. AF2240-L and AF2240-F came in second and third respectively in the number of matching homologous sequences. On the other hand, AF2240-HN, AF2240-NP and AF2240-P did not show much similarity with mammalian proteins. Importantly, we found many similarities between NDV protein sequences and Bcl-2 family members, especially for AF2240-L (Table 1). To narrow down our alignment studies, we compared Bcl-2 homology domains (BH1, BH2, BH3 and $\mathrm{BH} 4)$ of many $\mathrm{Bcl}-2$ family members with sequences from NDV viral proteins by SIM+LALNVIEW online software at ExPASy website and identified multiple $\mathrm{BH}$ domain-like regions in NDV viral proteins.

A highly similar $\mathrm{BH} 1$-like region was identified in AF2240-M matrix protein, with four out of eight residues being identical to those of Bax (Figure 2A). On the other hand, AF2240-F glycoprotein showed 55\% BH1 similarity with Mcl-1 by having five out of nine residues identical. Some known conserved residues of BH1 such as asparagine, glycine, valine, and leucine are present in both AF2240-M and AF2240-F. BH1-like regions are also present in AF2240-HN and AF2240-L proteins, but with far lower scores, with at most four out of nine matching residues. Thus, they were not further considered due to the lack of conserved residues. Moreover, we found similar BH3-like regions in AF2240-L, AF2240-F, and AF2240-M proteins (Figure $2 \mathrm{C}$ ). Within this domain, the amino acids leucine, glycine, and aspartic acid are highly conserved among various members of the Bcl-2 family and surprisingly, they are also present in all $\mathrm{BH} 3$-like regions in AF2240-L, AF2240-F and AF2240-M proteins. Our alignment studies did not reveal any considerable $\mathrm{BH} 2$ - 
A

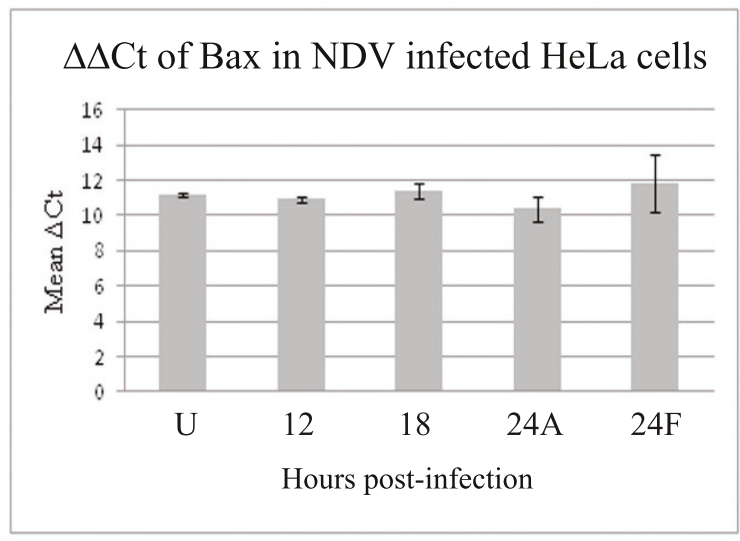

$\mathrm{C}$

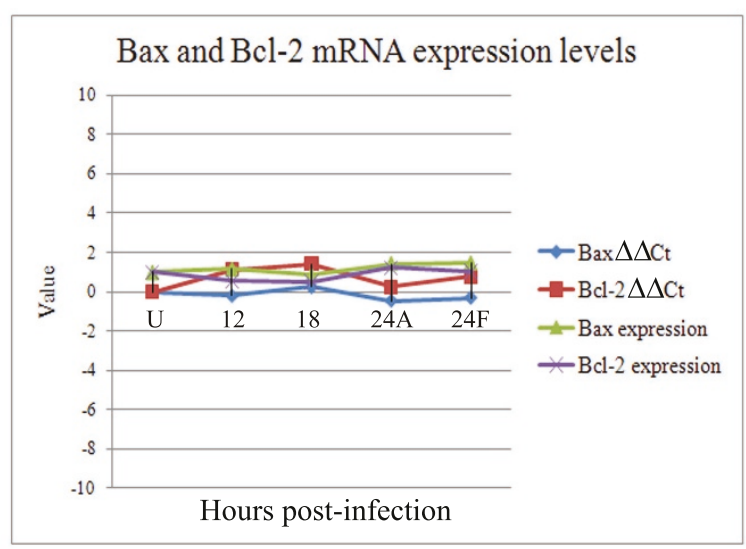

B

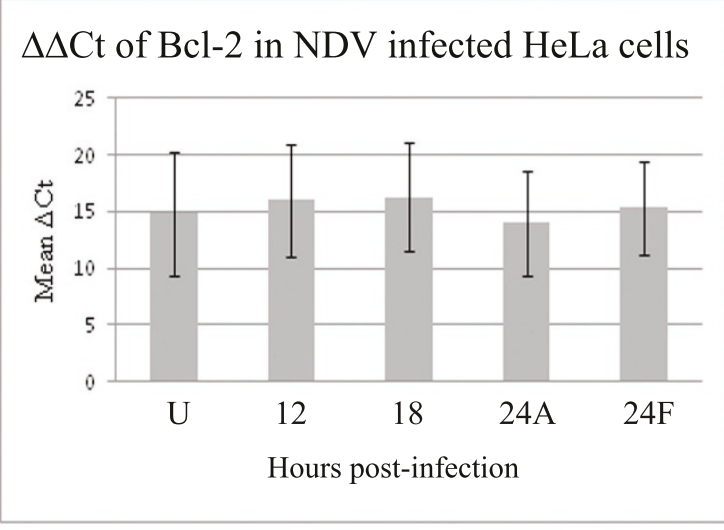

$\mathrm{D}$

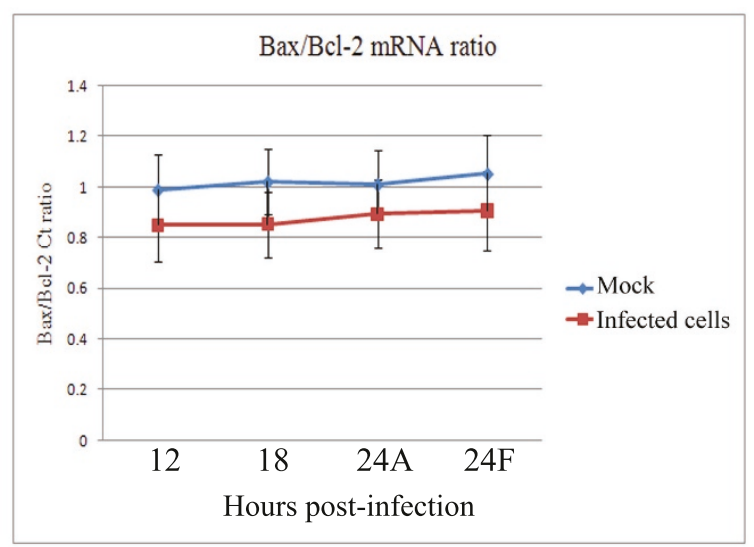

Figure 1 Real-Time PCR results showing expression of Bax and Bcl-2 mRNAs in HeLa cells following infection with NDV. A. $\triangle C$ t of Bax mRNA. B. $\triangle \mathrm{Ct}$ of Bcl-2 mRNA. C. Bax and Bcl-2 mRNA expression levels. D. Ratio of Bax to Bcl-2 Ct values. Note: All values were against housekeeping gene 18s rRNA Ct values. No statistically significant difference versus uninfected control cells was observed. Error bars indicate standard error of the mean from three independent measurements. U: uninfected cells. A: adherent infected cells. F: floating infected cells.

or BH4-like region in any of the NDV viral proteins. The closest sequences are shown in Figure $2 \mathrm{~B}$ for $\mathrm{BH} 2$, and Figure 2D for $\mathrm{BH} 4$, but most conserved residues are missing.

Subsequently, the BH3-like regions of AF2240 proteins were aligned with each other to investigate their similarity (Figure 2E). The AF2240-HN glycoprotein, which showed low similarity to those of Bcl-2 family, surprisingly, had up to six matching residues with AF2240-F glycoprotein. Although this region is not entirely considered a BH3-like region, AF2240-HN only lacked one conserved residue, glycine.

AF2240 shows unique features compared to other strains All BH3-like sequences of AF2240 were compared to five other known NDV strains (Figure 3). The residues threonine 38 and glycine 2130, in the BH3-like domain of AF2240-M and AF2240-L respectively, are unique to the strain AF2240. Other strains show some shared residues which are not present in AF2240-L at all. AF2240-F does not show any uniqueness and most residues are similar to the other five strains. Only strain La Sota shows a different methionine residue in the $\mathrm{BH} 3$-like region of its $\mathrm{F}$ protein.

Both BH1- and BH3-like regions of AF2240-M matrix protein are located within the $\mathrm{N}$-terminal segment of the protein (a.a. 99-107 and 27-32, respectively; Figure 4A). In addition, by using TMHMM software, we showed that the $\mathrm{BH}$-like region in $\mathrm{M}$ protein is located in the only area that exhibits a minor transmembrane binding ability in AF2240-M (data not shown). Later we generated the mutant AF2240-M- $\triangle \mathrm{BH} 3$ that lacked the entire BH3-like region between amino acids 23-37 (Figure $4 \mathrm{~B})$, in order to study the effect on cell death and further analyze the region.

The BH3-like region on AF2240-F protein is located within F glycoprotein F2 sequence between a.a. 88 to 
Table 1 Homologous regions between NDV viral proteins and human cellular proteins.

\begin{tabular}{|c|c|c|c|c|}
\hline Names & Sequences & Identity \% & Score (Bits) & Gap \% \\
\hline $\begin{array}{l}\text { AF2240-M } \\
\text { B-cell transcription factor } 4 \text { leukemia }\end{array}$ & $\begin{array}{l}27 \text { LQDTGDGKKQI } 38 \text { LQDTGDILQQI } \\
* * * * * * *\end{array}$ & 72.7 & 36.0 & 0.0 \\
\hline $\begin{array}{l}\text { AF2240-M } \\
\text { Glucagon-like } 1 \text { receptor }\end{array}$ & $\begin{array}{l}297 \text { QWDSLLSYSKCLS } \\
213 \text { QWDGLLSYQDSLS } \\
\star * \star \star * * * * *\end{array}$ & 69.0 & 27.8 & 0.0 \\
\hline $\begin{array}{l}\text { AF2240-M } \\
\text { Cholecystokinin B receptor }\end{array}$ & $\begin{array}{l}128 \text { VFSVVQA-PRVLQ } \\
191 \text { VYTVVQPVGPRVLQ } \\
\star * * * * * * \star\end{array}$ & 64.0 & 26.9 & 14.0 \\
\hline $\begin{array}{l}\text { AF2240-M } \\
\text { Fibrous sheath-interacting } 2\end{array}$ & $\begin{array}{l}150 \text { SVNAVNHVK } \\
1506 \text { SVNGGNHIK } \\
\star * * * * *\end{array}$ & 66.0 & 20.2 & 0.0 \\
\hline $\begin{array}{l}\text { AF2240-M } \\
\text { Spectrin beta chain, brain } 4\end{array}$ & $\begin{array}{l}46 \text { LDSWTDS } \\
2484 \text { LDSWTDS } \\
\star \star * \star * * *\end{array}$ & 100.0 & 26.5 & 0.0 \\
\hline $\begin{array}{l}\text { AF2240-M } \\
\text { Cytochrome Oxidase }\end{array}$ & $\begin{array}{l}182 \text { WDSLASFRKSLSP } \\
298 \text { WDSLLSYSKCLSP } \\
\star \star \star \star \star \star \star * \star\end{array}$ & 69.2 & 49.0 & 0.0 \\
\hline $\begin{array}{l}\text { AF2240-M } \\
\text { RAS p21 protein activator }\end{array}$ & 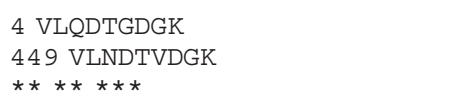 & 77.0 & 21.0 & 0.0 \\
\hline $\begin{array}{l}\text { AF2240-M } \\
\text { Bid }\end{array}$ & $\begin{array}{l}80 \text { DNPGHEL } 95 \text { DALGHEL } \\
* * * * *\end{array}$ & 71.4 & 24.0 & 0.0 \\
\hline $\begin{array}{l}\text { AF2240-M } \\
\text { Bax }\end{array}$ & $\begin{array}{l}298 \text { WDSLLSY } \\
158 \text { WDGLLSY } \\
\star * * * * *\end{array}$ & 85.7 & 46.0 & 0.0 \\
\hline $\begin{array}{l}\text { AF2240-L } \\
\text { BCl-2 }\end{array}$ & $\begin{array}{l}1540 \text { DFIEMSAKL } \\
110 \text { DFAEMSSQL } \\
\star * \star \star * *\end{array}$ & 66.7 & 31.0 & 0.0 \\
\hline $\begin{array}{l}\text { AF2240-L } \\
\text { Bid }\end{array}$ & $\begin{array}{l}19 \text { NTSRSEE } \\
147 \text { NVSRSEE } \\
\star \star \star \star \star \star\end{array}$ & 85.7 & 29.0 & 0.0 \\
\hline $\begin{array}{l}\text { AF2240-L } \\
\text { Bid }\end{array}$ & $\begin{array}{l}86 \text { LRTYVR } 2145 \text { LRTYLR } \\
\star \star \star \star *\end{array}$ & 83.3 & 27.0 & 0.0 \\
\hline $\begin{array}{l}\text { AF2240-L } \\
\text { Bad }\end{array}$ & $\begin{array}{l}451 \text { EFEPCIEYD } \\
6 \text { EFEPSEQED } \\
\star * * * *\end{array}$ & 55.6 & 25.0 & 0.0 \\
\hline $\begin{array}{l}\text { AF2240-F } \\
\text { F-box protein FBW7 }\end{array}$ & $\begin{array}{l}21 \text { LILSCICL } \\
8 \text { LILSCICL } \\
\star \star \star \star \star \star \star \star\end{array}$ & 100.0 & 29.9 & 0.0 \\
\hline
\end{tabular}

AF2240-M showed most matching sequences both to cellular proteins and also Bcl-2 family members compared to other viral proteins and strains.

102 (Figure 4C), right before the cleavage site at a.a. 116-117. BH1-like region of AF2240-F is located in the C-terminal end between a.a. 411-419, located on F1 before the transmembrane domain at a.a. 501-527 [11]. This observation was further confirmed by TMHMM prediction software (data not shown). Both Bcl-2 homology domain-like regions on AF2240-F are not within any of the hapted repeats or glycosylation sites.

Compared to members of the Bcl-2 family, the Bax protein has the highest identity-hits with AF2240-M. Subsequently, we also found out that the Bax protein has the highest sequence homology with AF2240-M protein compared to other tested NDV strains. We also found a homologous sequence WDSLLSY (Table 1), with $85.7 \%$ identity to the $\alpha-8$ helix sequence of Bax protein. This sequence is a part of the $\mathrm{BH} 2$ domain of Bax [35] and surprisingly, no other Bcl-2 family member shows any higher homology rate with Bax, than AF2240-M does.

The PELE software also showed that $\mathrm{BH}$-like regions of AF2240-L, AF2240-F and AF2240-M were all in random-coil regions and the BH3-like region of AF2240-F is right after a Beta-strand, but none of them are in helical areas, unlike those of many Bcl- 2 family members.

AF2240-M and AF2240-F transfections promote apoptosis To assess the effect of $M$ and $F$ proteins in cell death regulation, AF2240-M and AF2240-F cDNAs were cloned into pFLAG-CMV-5a vector and transfected into HeLa cells. Cells viability was analysed by flow cytometry and fluorescence microscopy. We found that AF2240-M transfection caused rounding up of cells and membrane blebbing as early as $12 \mathrm{~h}$ post-transfection. 


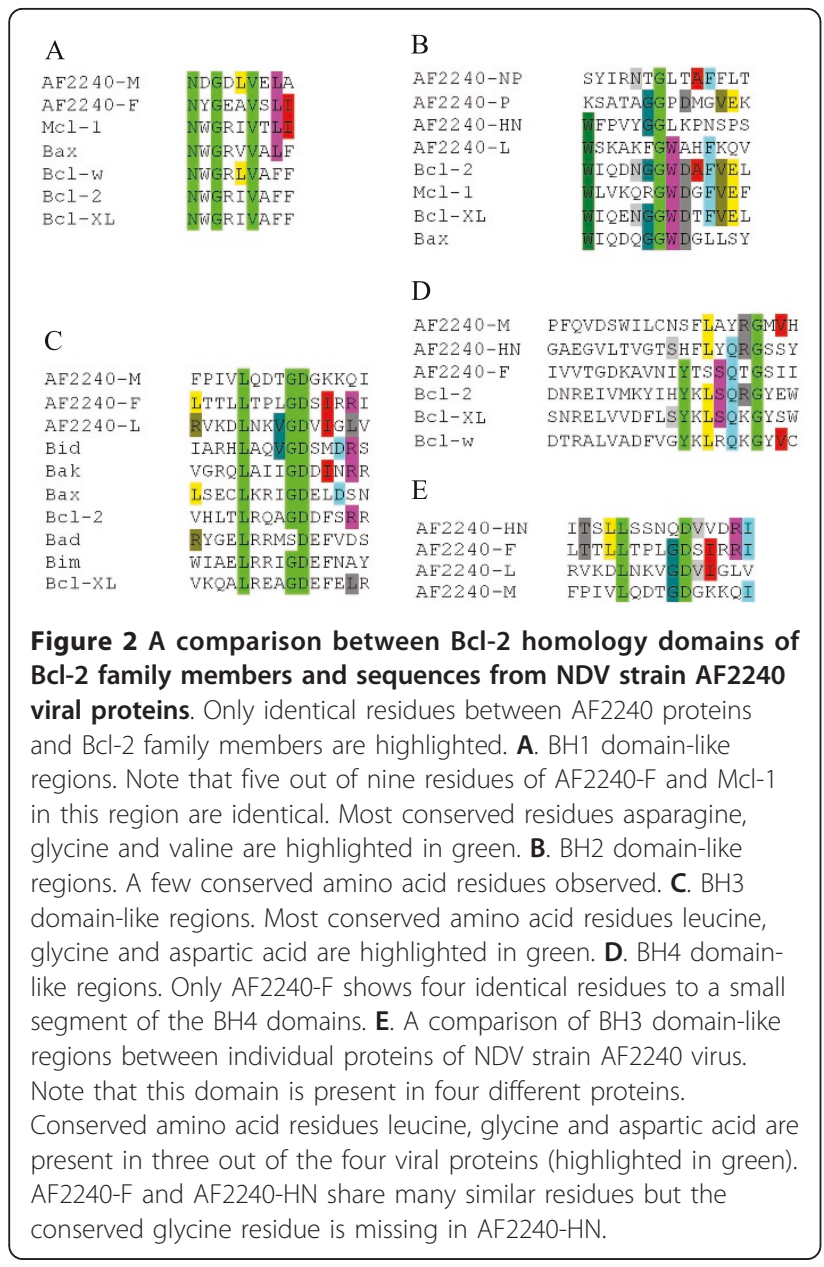

Cell death was then confirmed by PI staining and analysis by flow cytometer at $24 \mathrm{~h}$ and $48 \mathrm{~h}$ post-transfection (Figure 5A).

To determine the role of the BH3 domain in NDV viral protein-induced cell death, we truncated the BH3 domain of $\mathrm{M}$ and transfected the resulting mutant construct into HeLa cells. As shown in Figure 5A, truncation of the $\mathrm{BH} 3$ domain resulted in a nearly five-fold decrease in cell death compared to the wild-type AF2240-M (from $21.49 \%$ down to $4.32 \%$ ). In addition, we showed that transfection of the plasmid containing the N-terminal segment of AF2240-M (40 a.a.) also led

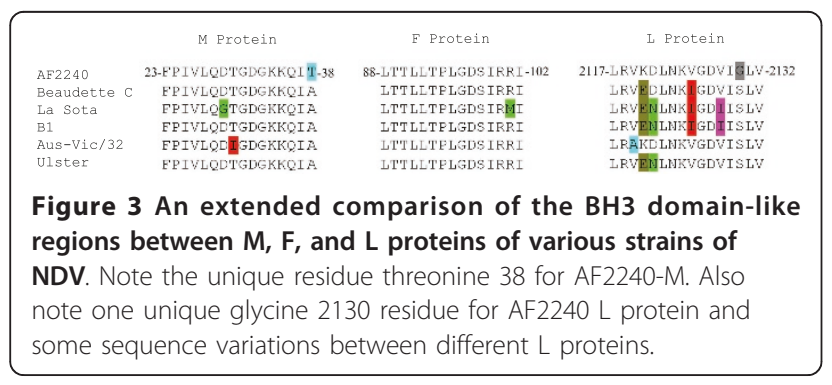

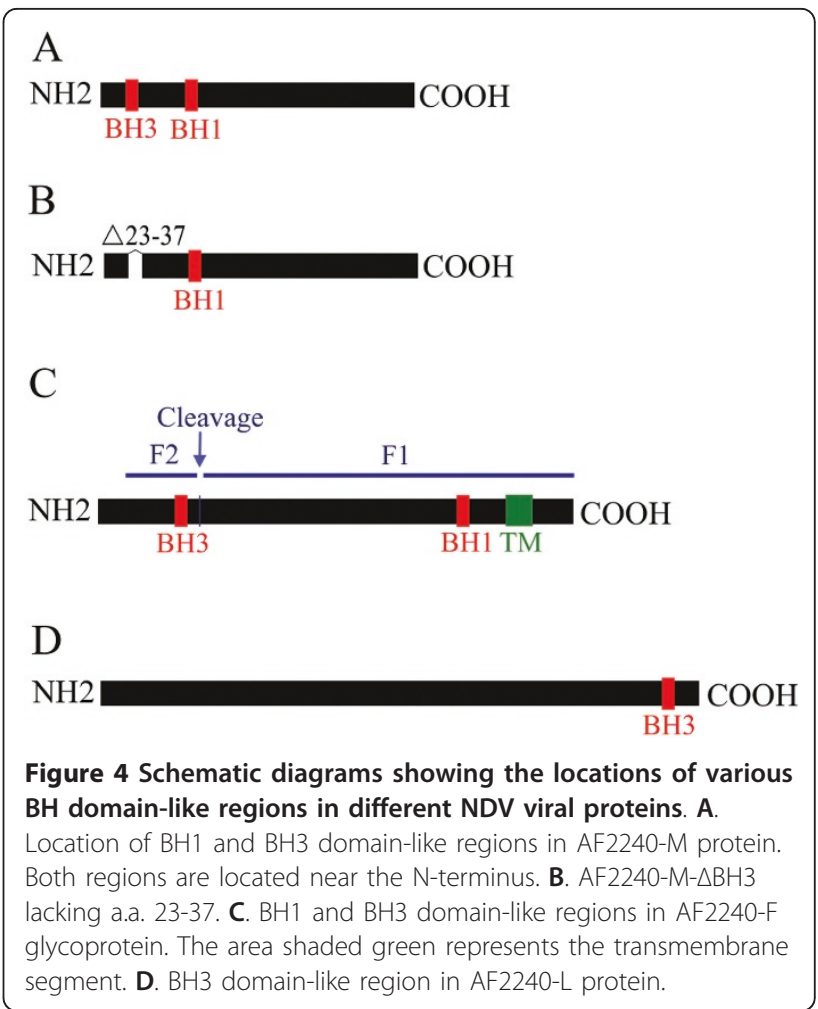

to apoptosis, and the rate was almost comparable to the full-length AF2240-M (21.21\%). pFLAG-F showed 12\% less cell death compared to pFLAG-M and this was further evaluated by histogram analyses shown in Figure 5B. We observed a shift for the G0/G1 phase peak in the cells transfected with pFLAG-M and pFLAG-F compared to untransfected cells, although the reading threshold was kept constant for each sample $(10,000$ events/run).

In addition to PI staining and flow cytometry analysis, we examined the nuclear morphology of transfected cells. AF2240-M cDNA was subcloned into the pEGFP. $\mathrm{N} 2$ vector. The resulting pEGFP-M construct or pEGFP. $\mathrm{N} 2$ control vector was transfected into HeLa cells and stained with DAPI (Figure 6). Transfection with pEGFP$M$ led to cell death as evidenced by the presence of numerous condensed and fragmented nuclei. On the other hand, in the pEGFP.N2 vector control transfected cells, the nuclei remained mostly intact.

Moreover, in order to study the localization of Bax following transfection with pEGFP-M subcellular fractionation was carried out (Figure 7). Cytosolic and heavy membrane fractions containing mitochondria were subjected to Western blotting analysis with the anti-Bax 2D2 antibody. Bax was primarily localized to the cytosolic fraction before transfection. However, the Bax level was decreased in the cytosolic fraction following transfection with pEGFP-M. In contrast, the Bax level was 


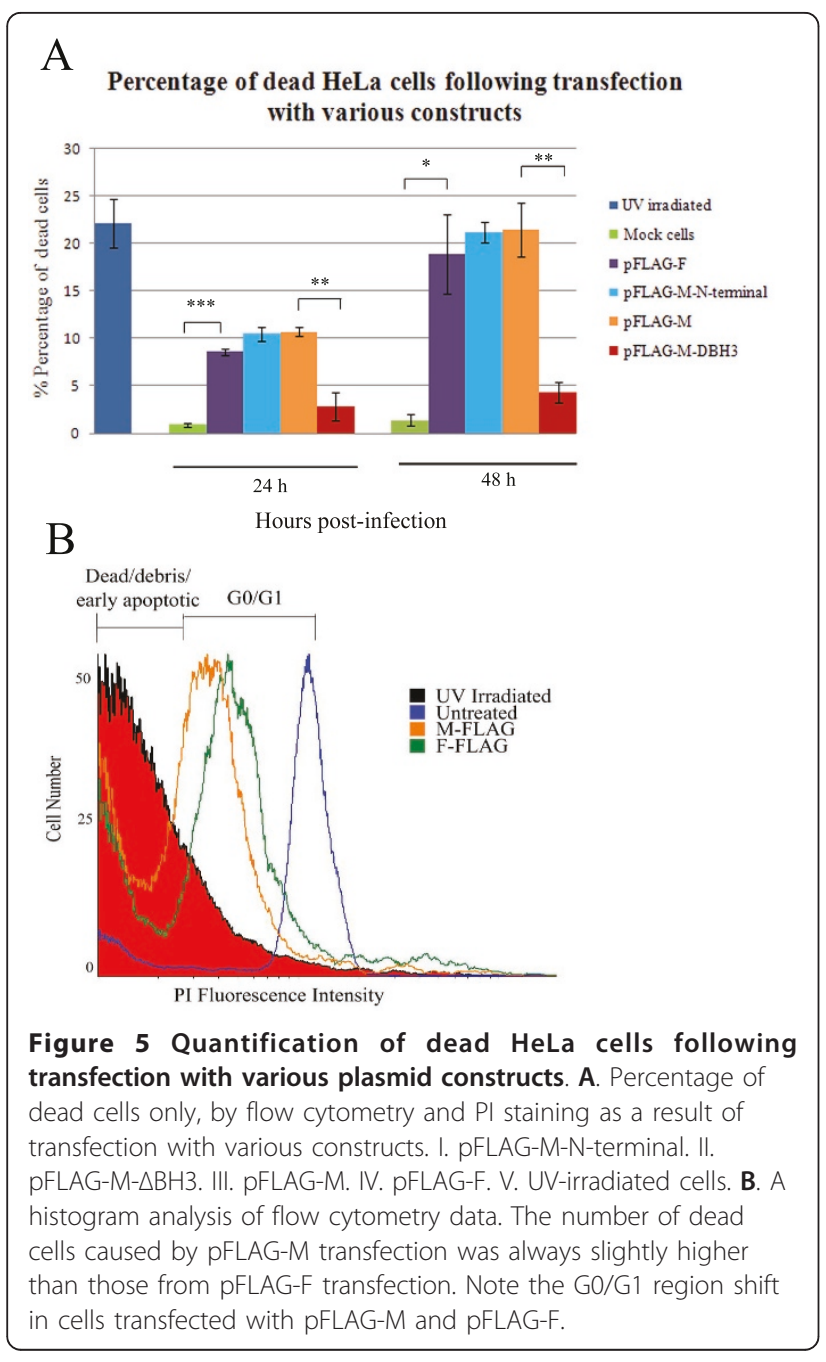

increased in the heavy membrane fraction of transfected cells, especially that obtained from the floating cells.

\section{AF2240-M binds to human Bax}

HeLa cells were co-transfected with pGFP-Bax, pGFPBad or pGFP-Bcl-XL and pFLAG-M. At different time points post-transfection, cells were lysed in $2 \%$ CHAPS buffer as described above. Co-IP was carried out by incubation of the cell lysate with anti-FLAG M2-coated protein $\mathrm{G}$ agarose beads. Later, the samples were run on SDS-PAGE and subjected to two separate immunoblottings with anti-FLAG M2 and anti-GFP primary antibodies (Figure 8). Interestingly, GFP-Bax band was detected in anti-GFP treated blotting membranes, revealing that FLAG-tagged AF2240-M directly interacted with GFP-Bax. In addition, anti-FLAG M2 was able to label FLAG-tagged AF2240-M on the membrane, confirming successful purification of the protein by the resin. The GFP-Bad and GFP-Bcl-XL did not show such interaction with AF2240-M.
In addition, it was shown that the rate of cell death caused by pFLAG-F was decreased dramatically (fivefold) when it was co-transfected with equal amount of pGFP-Bcl-XL (Figure 9A). However, the co-IP experiments showed no interaction between GFP-Bax, GFPBad or GFP-Bcl-XL and FLAG-tagged AF2240-F. Moreover, in a parallel experiment, the cells were co-transfected with pcDNA3-FLAG-BimL and pEGFP-M, but no interaction was observed either (data not shown).

\section{AF2240-M interacts by its $\mathrm{BH} 3$ domain}

In order to investigate if the BH3 domain in AF2240-M is responsible for binding to Bax, the truncated pFLAG$\mathrm{M}-\triangle \mathrm{BH} 3$ was co-transfected with pGFP-Bax. After coIP, although FLAG-tagged AF2240-M- $\triangle B H 3$ was present on the membrane blotted with anti-FLAG M2, no GFP-Bax was detected on the membranes blotted with anti-GFP (Figure 10). This showed that FLAG-tagged AF2240-M- $\triangle \mathrm{BH} 3$ is not able to bind to GFP-Bax.

\section{Discussion}

Our previous results did not show any significant changes in the total levels of Bax and Bcl-2 proteins following infection of HeLa cells with NDV [15]. In agreement with that, here we have shown that after infection with NDV, there was very little alteration on the mRNA levels of Bax and Bcl-2 from those levels (Figure 1). However, this event could also be strain and/or cell line-dependent; as shown previously [36], the Bax to Bcl-2 ratio in Vero cells following NDV infection changes. It has been observed that after infection of these cells with NDV, the Bax expression increased whereas Bcl-2 expression decreased. Therefore, it could be concluded that NDV-induced apoptosis in these two cell lines could follow different mechanisms.

Previously, we have shown that AF2240 causes cell death in HeLa cells within 24 h [15]. This event is associated with Bax conformational change and translocation from the cytoplasm to mitochondria. Subsequently cytochrome c is released from mitochondria and contributes to cell death via the intrinsic pathway of apoptosis. In the current study, we further investigated the reason behind pro-apoptotic ability of NDV by demonstrating that AF2240-M, AF2240-F and AF2240-L proteins contain $\mathrm{BH}$ domain-like regions (Figure 2). By cloning the AF2240-F and AF2240-M genes (that both contain $\mathrm{BH} 1$ - and BH3-like domains) into expression vectors and transfecting them into HeLa cells, it was shown that the expressed proteins displayed pro-apoptotic effect (Figure 5). Later, we showed that mutant AF2240-M$\triangle \mathrm{BH} 3$ had nearly five-fold decrease in cell death rate compared to the wild-type, while AF2240-M-N-terminal had the same rate of cell death as to that of the fulllength AF2240-M (Figure 5A). 
A

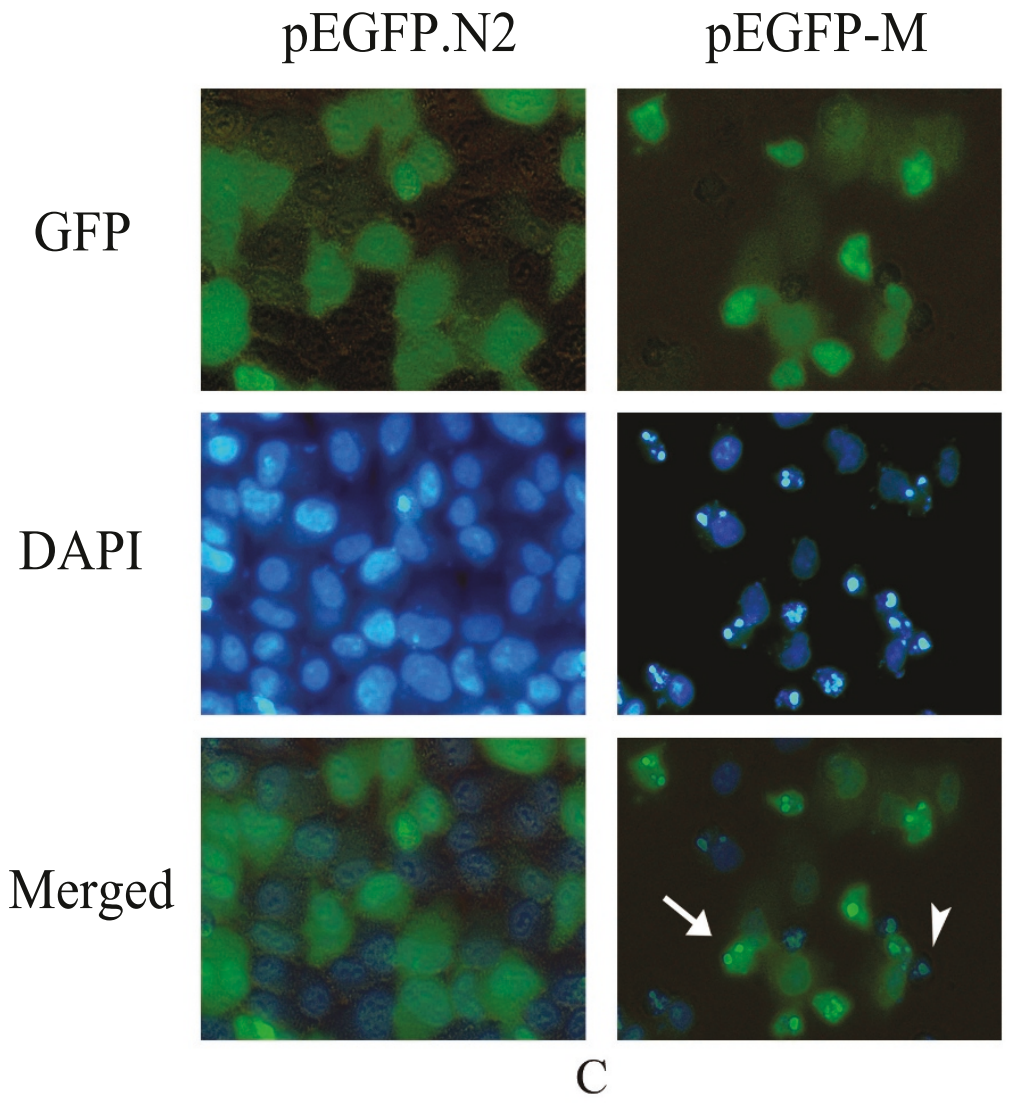

B

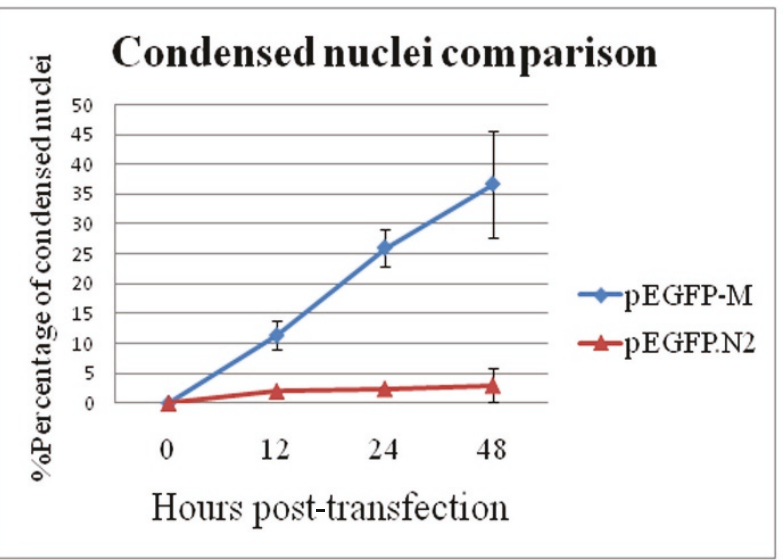

Figure 6 Transient transfection of HeLa cells with pEGFP-M leads to apoptosis. A. HeLa cells were transfected with either pEGFP or pEGFP$\mathrm{M}$ construct. At $20 \mathrm{~h}$ post-transfection, cells were stained with DAPI and visualized by fluorescence microscopy. Arrow indicates a dead EGFP-Mpositive cells. Arrow-head indicates a dead cell that may have lost its fluorescence due to possible degradation of EGFP-M protein. B. Percentage of condensed nuclei as compared to control. C. Percentage of EGFP-positive cells. Each data point represents three independent measurements, and the error bars indicate the standard error of the mean.

Therefore, it was very likely that the BH domain-like regions are responsible for the apoptotic effect of NDV viral proteins and that they might interact with $\mathrm{Bcl}-2$ family members. To further investigate, several plasmid constructs were co-transfected with another into HeLa cells. Based on co-IP, it was found that the FLAG-tagged
AF2240-M indeed directly bound to the GFP-Bax protein (Figure 8 ). All other tested proteins of the Bcl-2 family failed to interact with either AF2240-M or AF2240-F. Furthermore, FLAG-tagged AF2240-M- $\triangle \mathrm{BH} 3$ failed to interact with GFP-Bax proving that the binding occured via the BH3 domain of AF2240-M (Figure 10). It was 


\begin{tabular}{|rcccccc|}
\hline & c.u & c.a & c.f & m.u & m.a & m.f \\
$21 \mathrm{kDa}$ & & & & & & \\
\hline
\end{tabular}

Figure 7 Subcellular localization of Bax in pEGFP-M-transfected HeLa cells. At $20 \mathrm{~h}$ post-transfection the protein samples were analyzed by Western blotting analysis with the anti-Bax 2D2 antibody. Transfected adherent cells were collected separately from transfected floating cells $(c=$ cytosolic fraction, $m=$ heavy membrane fraction, $u=$ untransfected cells, $a=$ transfected adherent cells, $f=$ transfected floating cells). Bax translocated to the heavy membrane fraction after transfection with pEGFP-M, especially in transfected floating cells.

concluded that the AF2240-M can also directly bind to human Bax following NDV infection as long as the plasmid constructs expressed proteins that resembled their natural forms.

Together with our previous results, it could be concluded that binding of the AF2240-M to the endogenous Bax results in activation of Bax and consequently contributes to its translocation to the outer membrane of mitochondria (Figure 7), facilitating the release of mitochondrial factors such as cytochrome c. It should be reminded that each NDV virus particle contains a large number of $\mathrm{M}$ protein molecules in the inner side of its membrane. After NDV entry, all viral proteins are released inside the host cell, and therefore each $\mathrm{M}$ protein molecule could potentially act as a killer agent to promote apoptosis. On the other hand, it has been reported that inactive NDV virus (either chemically fixed or UV-irradiated) can also exhibit pro-apoptotic

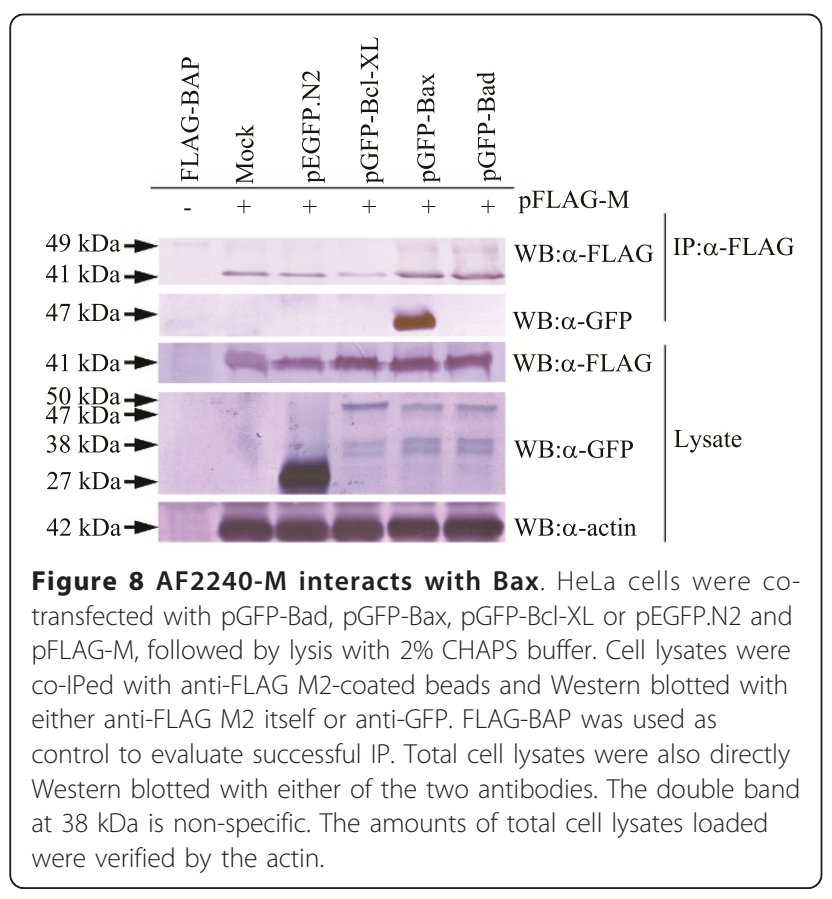

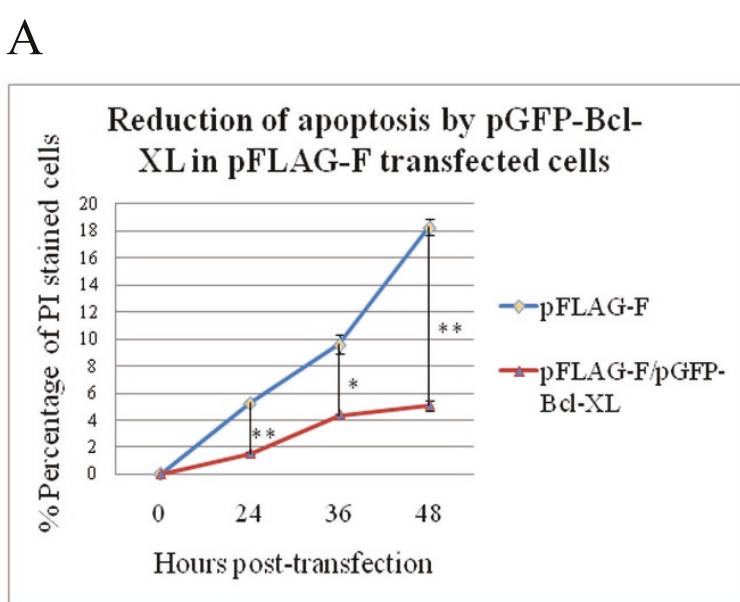

B

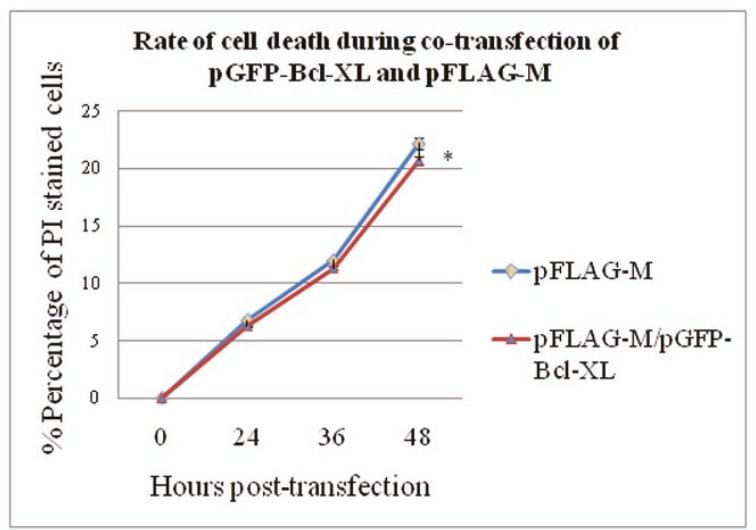

Figure 9 Flow cytometry data after co-transfection of pFLAG-M or pFLAG-F with pGFP-Bcl-XL. A. pGFP-BCl-XL reduces the cell death caused by pFLAG-F by nearly five-fold. B. pGFP-BCl-XL's effect on the rate of cell death caused by pFLAG-M was less significant. Data are obtained at different time points 24 h, 36 h and 48 h. Each data point represents three independent measurements, and the error bars indicate the standard error of the mean. ${ }^{*}, p<0.05$ and **, $p<0.01$ were referred to as statistically significant differences.

ability $[37,38]$. Moreover, it has been shown that the substitutions of both $\mathrm{HN}$ and $\mathrm{F}$ proteins of mesogenic strains with velogenic strains did not alter nor increase the virulence of the virus [39], suggesting other factors are involved. These findings further supported our hypothesis that the $\mathrm{M}$ protein is a major candidate for the behavior of NDV.

As shown in Figure 5A, transfection of cells with pFLAG-F led to cell death, albeit somewhat lower compared to pFLAG-M. Surprisingly, co-transfection of pFLAG-F and the same amount of pGFP-Bcl-XL led to a dramatic five-fold drop of death rate (Figure 9A). This suggests a possible intracellular inhibition of AF2240-F by Bcl-XL. However, no interaction between FLAGtagged AF2240-F and GFP-Bcl-XL was observed. Possibly, 


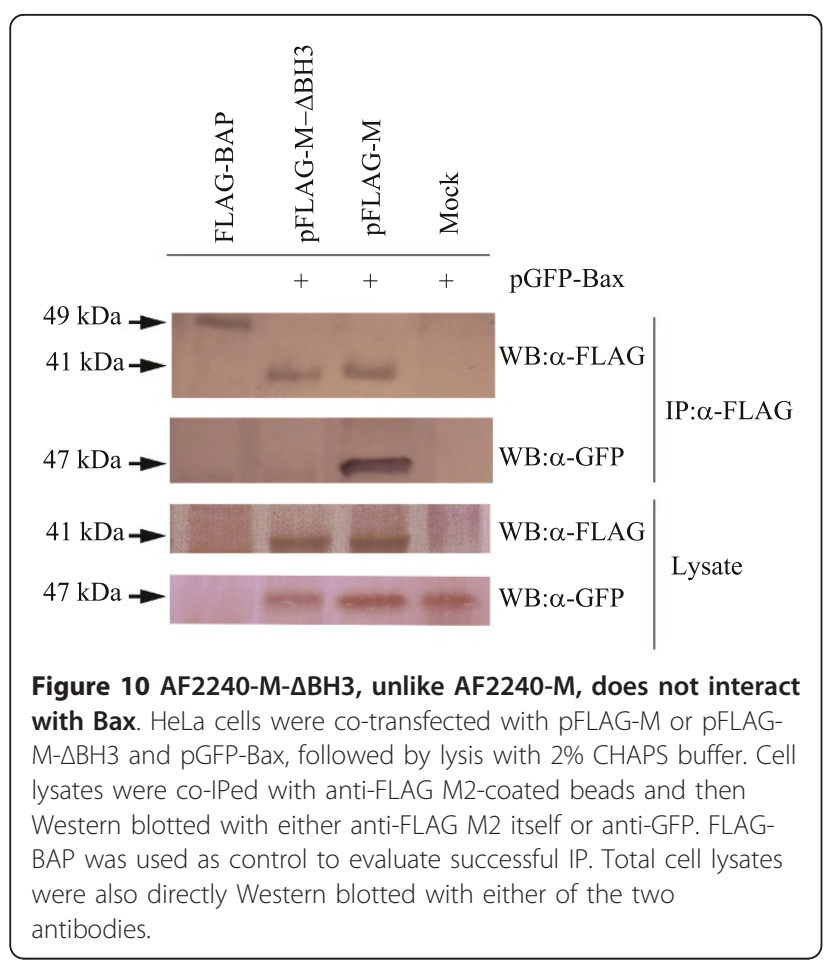

GFP-Bcl-XL inhibits other mechanisms downstream of the action of AF2240-F. In contrast, the reduction of apoptosis in pGFP-Bcl-XL and pFLAG-M co-transfected cells was not as significant as pGFP-Bcl-XL and pFLAGF co-transfected cells (Figure 9B). Perhaps, AF2240-F and AF2240-M follow different pathways of apoptosis and/or GFP-Bcl-XL is not able to sufficiently prevent AF2240-M.

$\mathrm{BH} 3$-like region of AF2240-M is located within the $\mathrm{N}$-terminal segment of the protein (a.a. 27-32). On the other hand and as stated before, the NDV M protein is believed to play an important role in the assembly of the virus by interacting with the nucleocapsid, the lipid bilayer and also the regions of the surface glycoproteins that are exposed on the inner surface of the membrane, but the domains on the $\mathrm{M}$ protein that are involved in binding with the three macromolecules have yet to be delineated [7]. Surprisingly, by using TMHMM software, we revealed that BH3-like region in AF2240-M protein is located in the only area that exhibits a minor transmembrane binding ability. Therefore, since many Bcl-2 family members interact with each other via their $\mathrm{BH} 3$ domain, further investigation is needed to show whether NDV M protein interacts with other NDV viral proteins via this domain.

It should be highlighted that although AF2240-L showed a higher sequence similarity to the $\mathrm{BH} 3$ domain compared to the rest of the viral proteins (Figure 2C), there is limitation for cloning and transfection studies because of the length of its gene (6615 bp).

On the other hand, a number of viral proteins have been identified that share homology with mammalian proteins and display either an anti- or pro-apoptotic effect upon introduction into host cells. We have tabulated some of these viral proteins that share a partial sequence similarity with $\mathrm{Bcl}-2$ family members in Table 2. Many of these proteins contain Bcl-2 homology domains and interact with one or more Bcl-2 family members. For example, gamma-herpesviruses and few other herpesviruses encode at least one homolog of Bcl2 [40]. African swine fever virus and Adenovirus encode at least two proteins with $\mathrm{BH} 3$ domains that mainly interact with pro-apoptotic members of Bcl-2 family $[23,27,28,41]$. However, most of these viral proteins show anti-apoptotic effect, and only few of them such as HCV core protein and HBV HBSP demonstrate pro-

Table 2 Viral proteins that resemble Bcl-2 family members by having one or more BH-like domains

\begin{tabular}{|c|c|c|c|c|c|c|}
\hline Name & $\begin{array}{l}\text { Viral } \\
\text { Protein }\end{array}$ & Function & Interacts With & $\begin{array}{l}\text { Does Not Interact } \\
\text { With }\end{array}$ & Annotation & Reference \\
\hline Vaccinia Virus & FL1 & Anti-apoptotic & Bax, Bak, Bim & - & BH3 Domain & {$[29,45]$} \\
\hline $\mathrm{HCV}$ & $\begin{array}{l}\text { Core } \\
\text { protein }\end{array}$ & Pro-apoptotic & $\mathrm{Mcl}-1$ & $\mathrm{BCl}-\mathrm{XL}, \mathrm{BCl}-\mathrm{W}$ & BH3 Domain & {$[46]$} \\
\hline Epstein-Barr Virus & BHRF1 & Anti-apoptotic & Bax, Bak, Bim & - & BH3 Binding Groove & {$[21,22,47]$} \\
\hline Gamma-Herpes Virus 68 & $\mathrm{M} 11, \mathrm{vBCl}-2$ & Anti-apoptotic & Bim & - & - & {$[40,48]$} \\
\hline Myxoma Virus & $\mathrm{M} 11 \mathrm{~L}$ & Anti-apoptotic & Bak & - & BH3 Domain & [49] \\
\hline African Swine Virus & $\mathrm{A} 179 \mathrm{~L}, 5-\mathrm{HL}$ & Anti-apoptotic & Bid, Bax, Bak, Noxa & - & BH1 Domain & {$[23,41]$} \\
\hline $\begin{array}{c}\text { Kaposi Sarcoma-Associated } \\
\text { Virus }\end{array}$ & ORF K12 & Anti-apoptotic & - & Bak, Bax & $\begin{array}{c}\text { Human Herpesvirus-8. } 9 \\
\text { Homologs }\end{array}$ & {$[24,25,50]$} \\
\hline HBV & HBSP & Pro-apoptotic & - & - & BH3 Domain & {$[51]$} \\
\hline Herpesvirus Saimiri & ORF16 & Anti-apoptotic & Bax, Bak & - & Conserved $\mathrm{BH} 1, \mathrm{BH} 2$. No $\mathrm{BH} 3$ & {$[26,52]$} \\
\hline Orf Virus & ORFV125 & Anti-apoptotic & $\begin{array}{l}\text { Bik, Puma, Noxa, } \\
\text { Bim }\end{array}$ & Inactive form of Bax & BH3 Domain & [53] \\
\hline Adenovirus & E1B-19K & Anti-apoptotic, & Bax & $\mathrm{BCl}-2$ & BH3 Domain & {$[28]$} \\
\hline
\end{tabular}

So far only few viral proteins discovered show pro-apoptotic characteristics compared to the rest with anti-apoptotic effects. 
apoptotic effect. Here, we added NDV and its viral proteins to this group as not only they contain $\mathrm{BH} 1$ - and BH3-like domains and display a pro-apoptotic property, but also AF2240-M interacts with Bax via its BH3 domain. Similar regions between Bcl-2 family and NDV proteins could have evolved during early evolution.

The BH3 domain is mainly considered as a pro-apoptotic domain of the Bcl-2 family of proteins [42]. Although the BH1 domain is generally a pro-survival domain, it is present in some of the pro-apoptotic members such as Bak and Bax. In this study, we show that although AF2240-M and AF2240-F proteins both contain BH1-like regions, they both display a pro-apoptotic function (Figure 5). However, BH1-like domain of AF2240-M was not found to be responsible for its interaction with Bax.

Not much is known about the mechanisms underlying the velogenicity of different strains of NDV, but there is now evidence that the cleavability of F0 is a major determinant for virulence of NDV virus $[43,44]$. Therefore, some might argue that a direct transfection of a plasmid containing full-length $\mathrm{F}$ gene would not fully demonstrate its pro-apoptotic ability as the expressed product has not undergone post-translational modification, and therefore it is not in its natural wild-type form. However, we noticed that the $\mathrm{BH} 1$ - and BH3-homologous regions of AF2240-F are not localised within any of the previously characterised regions (i.e. HR regions, cleavage site, glycosylation regions, or transmembrane segment). Thus, AF2240-F could still exert its apoptotic effect whether it is in its full-length or cleaved form. On the other hand, unlike $\mathrm{F}$ and $\mathrm{HN}$ glycoproteins of NDV, the M protein does not undergo cleavage and glycosylation. There has been no report showing that $M$ core protein has a major post-translational cleavage similar to that of NDV surface proteins. Therefore, transfection of a fulllength $M$ gene and elicitation of its pro-apoptotic effect would unlikely to be regulated by post-translational modification.

AF2240 is a velogenic strain that causes severe intestinal lesions and neurological disorders, resulting in high mortality. Previously it was shown that AF2240-HN protein of this strain has a different length compared to those of other strains [30]. Compared to other NDV strains, the BH3 domain-like sequence in AF2240-M has threonine 38 residue in place of alanine (Figure 3). In addition, glycine 2130 is present in the $\mathrm{BH} 3$ domain-like sequence of AF2240-L protein in place of serine. On the other hand, most $\mathrm{L}$ proteins share residues that are not present in AF2240-L. These differences could potentially account for the velogenic characteristic of AF2240 compared to milder strains and this is in need of further investigation.
In conclusion, we have demonstrated that the NDV M protein is able to interact with human Bax protein by its BH3 domain. Such interactions could potentially account for the pro-apoptotic ability of NDV and ultimately lead us to better understanding of the viral mechanisms.

\section{Abbreviations}

ATCC: American type culture collection; DMEM: Dulbecco's modified Eagle's medium; FBS: Fetal bovine serum; BH domain: $\mathrm{BCl}-2$ homology domain; $\mathrm{Ct}$ : Cycle threshold.

\section{Acknowledgements}

Molouki A was supported by a GRF scholarship, UPM. This research was supported by the Malaysian Genome Institute Grant MGI-NBD0017-2007.

\section{Author details}

${ }^{1}$ Department of Microbiology, Faculty of Biotechnology and Biomolecular Sciences, Universiti Putra Malaysia, 43400 UPM, Serdang, Selangor DE, Malaysia. ${ }^{2}$ Department of Biochemistry and Molecular Biology, Medical University of South Carolina, Charleston, SC, USA. ${ }^{3}$ Department of Obstetrics and Gynaecology, Faculty of Medicine and Health Sciences, Universiti Putra Malaysia, 43400 UPM, Serdang, Selangor DE, Malaysia. ${ }^{4}$ Institute of Biosciences, Universiti Putra Malaysia, 43400, Serdang, Selangor DE, Malaysia.

\section{Authors' contributions}

AM designed and performed the experiments and drafted the manuscript. YTH participated in the design of the study, performed the data analysis and contributed to writing the manuscript. FJ assisted in the alignment studies. SA participated in the data analysis. RR conceived of the study and participated in its coordination. KY participated in the design of the study, financial support and contributed to writing the manuscript. All authors have read and approved the final manuscript.

\section{Competing interests}

The authors declare that they have no competing interests.

Received: 15 May 2011 Accepted: 3 August 2011

Published: 3 August 2011

\section{References}

1. Aldous EW, Alexander DJ: Newcastle disease in pheasants (Phasianus colchicus): a review. Vet J 2008, 175:181-185.

2. Lai MC, Ibrahim AL: Velogenic viscerotropic Newcastle disease virus. In Newcastle disease in poultry: a new food pellet vaccine. Volume monograph 5. Edited by: Copland JW. Canberra: ACIAR; 1987:33-34.

3. Mayo MA: A summary of taxonomic changes recently approved by ICTV. Arch Virol 2002, 147:1655-1663.

4. Krishnamurthy S, Samal SK: Nucleotide sequences of the trailer, nucleocapsid protein gene and intergenic regions of Newcastle disease virus strain Beaudette $C$ and completion of the entire genome sequence. J Gen Virol 1998, 79:2419-2424.

5. Phillips RJ, Samson ACR, Emmerson PT: Nucleotide sequence of the 59 -terminus of Newcastle disease virus and assembly of the complete genomic sequence: agreement with the "rule of six". Arch Virol 1998, 143:1993-2002.

6. de Leeuw OS, Peeters BP: Complete nucleotide sequence of Newcastle disease virus: evidence for the existence of a new genus within the subfamily Paramyxovirinae. J Gen Virol 1999, 80:131-136.

7. Yusoff K, Tan WS: Newcastle disease virus: macromolecules and opportunities. Avian Pathol 2001, 30:439-455.

8. Gotoh B, Ohnishi Y, Inocencio NM, Esaki E, Nakayama K, Barr PJ, Thomas G, Nagai $Y$ : Mammalian subtilisin-related proteinases in cleavage activation of the paramyxovirus fusion glycoprotein: superiority of furin/PACE to PC2 or PC1/PC3. J Virol 1992, 66:6391-6397.

9. Ogasawara T, Gotoh B, Suzuki H, Asaka J, Shimokata K, Rott R, Nagai Y Expression of factor $x$ and its significance for the determination of paramyxovirus ropism in the chick embryo. EMBO 1992, 11:467-472. 
10. Young JK, Li D, Abramowitz MC, Morrison TG: Interaction of peptides with sequences from the Newcastle disease virus fusion protein heptad repeat regions. J Virol 1999, 73:5945-5956.

11. Chambers P, Millar NS, Emmerson PT: Nucleotide sequence of the gene encoding the fusion glycoprotein of Newcastle disease virus. J Gen Virol 1986, 67:2685-2694.

12. Garcia-Sastre A, Cabezas JA, Villar E: Proteins of Newcastle disease virus envelope: interaction between the outer hemagglutinin-neuraminidase glycoprotein and the inner non-glycosylated matrix protein. Biochim Biophys Acta 1989, 999:171-175.

13. Reichard KW, Lorence RM, Cascino CJ, Peeples ME, Walter RJ, Fernando MB, Reyes HM, Greager JA: Newcastle disease virus selectively kills human tumor cells. Surg Res 1992, 52:448-453.

14. Lam KM, Vasconcelos AC, Bickford AA: Apoptosis as a cause of death in chicken embryos inoculated with Newcastle disease virus. Microb Pathog 1995, 19:169-174.

15. Molouki A, Hsu YT, Jahanshiri F, Rosli R, Yusoff K: Newcastle disease virus infection promotes Bax redistribution to mitochondria and cell death in HeLa cells. Intervirol 2010, 53:87-94.

16. Washburn B, Weigand MA, Grosse-Wilde A, Janke M, Stahl H, Rieser E, Sprick MR, Schirrmacher V, Walczak H: TNF-related apoptosis-inducing ligand mediates tumoricidal activity of human monocytes stimulated by Newcastle disease virus. J Immunol 2003, 170:1814-1821.

17. Ekert PG, Vaux DL: Apoptosis and the immune system. Br Med Bull 1997, 53:591-603.

18. Wang X: The expanding role of mitochondria in apoptosis. Genes Dev 2001, 15:2922-2933.

19. Oltvai ZN, Milliman $\mathrm{CL}$, Korsmeyer SJ: $\mathrm{Bcl}-2$ heterodimerizes in vivo with a conserved homolog, Bax, that accelerates programmed cell death. Cell 1993, 74:609-619.

20. Roulston A, Marcellus RC, Branton PE: Viruses and apoptosis. Annu Rev Microbiol 1999, 53:577-628.

21. Henderson S, Huen D, Rowe M, Dawson C, Johnson G, Rickinson A: Epstein-Barr virus-coded BHRF1 protein, a viral homologue of $\mathrm{BCl}-2$, protects human B cells from programmed cell death. Proc Natl Acad SCi USA 1993, 90:8479-8483.

22. Takayama S, Cazals-Hatem DL, Kitada S, Tanaka S, Miyashita T, Hovey LR, Huen D, Rickinson A, Veerapandian P, Krajewski S, authors o: Evolutionary conservation of function among mammalian, avian, and viral homologs of the Bcl-2 oncoprotein. DNA Cell Biol 1994, 13:679-692.

23. Brun A, Rivas C, Esteban M, Escribano JM, Alonso C: African swine fever virus gene $A 179 L$, a viral homologue of bcl-2, protects cells from programmed cell death. Virology 1996, 225:227-230.

24. Cheng EH, Nicholas J, Bellows DS, Hayward GS, Guo HG, Reitz MS, Hardwick JM: A Bcl-2 homolog encoded by Kaposi sarcoma-associated virus, human herpesvirus 8 , inhibits apoptosis but does not heterodimerize with Bax or Bak. Proc Natl Acad Sci USA 1997, 94:690-694.

25. Sarid R, Sato T, Bohenzky RA, Russo JJ, Chang Y: Kaposi's sarcoma-associated herpesvirus encodes a functional bcl-2 homologue. Nat Med 1997, 3:293-298.

26. Nava VE, Cheng EH, Veliuona M, Zou S, Clem RJ, Mayer ML, Hardwick JM: Herpesvirus saimiri encodes a functional homolog of the human bcl-2 oncogene. J Virol 1997, 71:4118-4122.

27. Yasuda M, Theodorakis P, Subramanian T, Chinnadurai G: Adenovirus E1B19K/BCL-2 interacting protein BNIP3 contains a BH3 domain and a mitochondrial targeting sequence. J Biol Chem 1998, 273:12415-12421.

28. Han J, Modha D, White E: Interaction of E1B $19 \mathrm{~K}$ with Bax is required to block Bax-induced loss of mitochondrial membrane potential and apoptosis. Oncogene 1998, 17:2993-3005.

29. Wasilenko ST, Stewart TL, Meyers AF, Barry M: Vaccinia virus encodes a previously uncharacterized mitochondrial-associated inhibitor of apoptosis. Proc Natl Acad Sci USA 2003, 100:14345-14350.

30. Tan WS, Lau CH, Ng BK, Ibrahim AL, Yusoff K: Nucleotide sequence of the haemagglutinin-neuraminidase $(\mathrm{HN})$ gene of a Malaysian heat resistant viscerotropic-velogenic Newcastle disease virus. DNA Seq 1995, 6:47-50.

31. Ramanujam P, Tan WS, Nathan S, Yusoff K: Novel peptides that inhibit the propagation of Newcastle disease virus. Arch Virol 2002, 147:981-993.

32. Zhou H, Hou Q, Chai Y, Hsu YT: Distinct domains of Bcl-XL are involved in Bax and Bad antagonism and in apoptosis inhibition. Exp Cell Res 2005, 309:316-328

33. Hsu YT, Wolter KG, Youle RJ: Cytosol-to-membrane redistribution of Bax and Bcl-X(L) during apoptosis. Proc Natl Acad Sci USA 1997, 94:3668-3672.
34. Hsu YT, Youle RJ: Bax in murine thymus is a soluble monomeric protein that displays differential detergent-induced conformations. J Biol Chem 1998, 273:10777-10783.

35. Suzuki M, Youle RJ, Tjandra N: Structure of Bax: coregulation of dimer formation and intracellular localization. Cell 2000, 103:645-654.

36. Ravindra PV, Tiwari AK, Ratta B, Chaturvedi U, Palia SK, Chauhan RS: Newcastle disease virus-induced cytopathic effect in infected cells is caused by apoptosis. Virus Res 2009, 141:13-20.

37. Yang S, Liu W, Cui H, Sun S, Wang J: In vitro induction of apoptosis in tumor cells by inactivated NDV and IAV. Cancer Biother Radiopharm 2007, 22:200-205.

38. Zeng J, Fournier P, Schirrmacher V: Induction of Interferon-[alpha] and Tumor Necrosis Factor-Related Apoptosis-Inducing Ligand in Human Blood Mononuclear Cells by Hemagglutinin-Neuraminidase but Not $\mathrm{F}$ Protein of Newcastle Disease Virus. Virology 2002, 297:19-30.

39. Estevez C, King D, Seal B, Yu Q: Evaluation of Newcastle disease virus chimeras expressing the hemagglutinin-neuraminidase protein of velogenic strains in the context of a mesogenic recombinant virus backbone. Virus Res 2007, 129:182-190.

40. Flanagan $\mathrm{AM}$, Letai $\mathrm{A}: \mathrm{BH} 3$ domains define selective inhibitory interactions with BHRF-1 and KSHV BCL-2. Cell Death Differ 2008 15:580-588.

41. Galindo I, Hernaez B, Diaz-Gil G, Escribano JM, Alonso C: A179L, a viral Bcl2 homologue, targets the core $\mathrm{Bcl}-2$ apoptotic machinery and its upstream $\mathrm{BH} 3$ activators with selective binding restrictions for Bid and Noxa. Virology 2008, 375:561-572.

42. Willis SN, Adams JM: Life in the balance: how BH3-only proteins induce apoptosis. Curr Opin Cell Biol 2005, 17:617-625

43. Peeters BPH, de Leeuw OS, Koch G, Gielkens AL: Rescue of Newcastle disease virus from cloned cDNA: evidence that cleavability of the fusion protein is a major determinant for virulence. J Virol 1999, 73:5001-5009.

44. de Leeuw OS, Koch G, Hartog L, Ravenshorst N, Peeters BPH: Virulence of Newcastle disease virus is determined by the cleavage site of the fusion protein and by both the stem region and globular head of the haemagglutinin-neuraminidase protein. J Gen Virol 2005, 86:1759-1769.

45. Taylor JM, Quilty D, Banadyga L, Barry M: The vaccinia virus protein F1L interacts with Bim and inhibits activation of the pro-apoptotic protein Bax. J Biol Chem 2006, 281:39728-39739.

46. Mohd-Ismail NK, Deng L, Sukumaran SK, Yu VC, Hotta H, Tan YJ: The hepatitis $\mathrm{C}$ virus core protein contains a $\mathrm{BH} 3$ domain that regulates apoptosis through specific interaction with human Mcl-1. J Virol 2009 83:9993-10006.

47. Desbien AL, Kappler JW, Marrack P: The Epstein-Barr virus Bcl-2 homolog BHRF1, blocks apoptosis by binding to a limited amount of Bim. Proc Natl Acad Sci USA 2009, 106:5663-5668.

48. Xiaofei E, Hwang S, Oh S, Lee JS, Jeong JH, Gwack Y, Kowalik TF, Sun R, Jung JU, Liang C: Viral Bcl-2-mediated evasion of autophagy aids chronic infection of gammaherpesvirus 68. PLoS Pathog 2009, 5:e1000609.

49. Douglas AE, Corbett KD, Berger JM, McFadden G, Handel TM: Structure of M11L: A myxoma virus structural homolog of the apoptosis inhibitor Bcl-2. Protein Sci 2007, 16:695-703.

50. Nicholas J, Ruvolo V, Zong J, Ciufo D, Guo HG, Reitz MS, Hayward GS: A single 13-kilobase divergent locus in the Kaposi sarcoma-associated herpesvirus (human herpesvirus 8 ) genome contains nine open reading frames that are homologous to or related to cellular proteins. J Virol 1997, 71:1963-1974.

51. Lu YW, Ren YD, Bai J, Chen WN: The spliced variant of hepatitis $B$ virus protein, $\mathrm{HBSP}$, interacts with $\mathrm{BCl}-2 / \mathrm{BCl}-\mathrm{xl}$ in vitro and induces apoptosis in HepG2 cells. IUBMB Life 2008, 60:700-702.

52. Derfuss $T$, Fickenscher $H$, Kraft MS, Henning G, Lengenfelder D, Fleckenstein B, Meinl E: Antiapoptotic activity of the herpesvirus saimiriencoded $\mathrm{BCl}-2$ homolog: stabilization of mitochondria and inhibition of caspase-3-like activity. J Virol 1998, 72:5897-5904.

53. Westphal D, Ledgerwood EC, Tyndall JD, Hibma MH, Ueda N, Fleming SB, Mercer AA: The orf virus inhibitor of apoptosis functions in a $\mathrm{BCl}$-2-like manner, binding and neutralizing a set of $\mathrm{BH}$-only proteins and active Bax. Apoptosis 2009, 14:1317-1330.

doi:10.1186/1743-422X-8-385

Cite this article as: Molouki et al:: The matrix (M) protein of Newcastle disease virus binds to human Bax through its $\mathrm{BH} 3$ domain. Virology Journal 2011 8:385. 